\title{
Corporate Investment in Sport Sponsorship and its Evaluation
}

\author{
By Abdullah Demirel ${ }^{*}$ \\ Irem Eren Erdogmus ${ }^{\dagger}$
}

Corporate investment in sponsorship has increased dramatically in recent decades and growth rate in sponsorship has exceeded any other marketing communications tool. Although spending on sponsorship is expected to increase more in the future and sport dominates the pie of sponsorship revenue, the relationship between sponsorship and purchase intentions of consumers is still vague and needs elaborate research. Current study is an attempt to contribute understanding of sponsorship in sport context and aims to evaluate sport sponsorship effectiveness by investigating antecedents of attitudes towards sponsor and purchase intentions. A conceptual model was developed to examine the effects of factors such as perceived sincerity, perceived fit between the sponsor and sport team and team attachment on attitude towards sponsor and intentions to purchase sponsor's products. The measurement model was tested using confirmatory factor analysis and hypothesized model was tested by using Structural equation modeling (SEM). The data were collected from spectators of a Turkish basketball game in the arena before the start of game. The results suggest that perceived fit and team attachment have positive influence on sincerity perceptions which in turn create positive attitudes toward sponsor and greater purchase intentions for products of sponsor. Findings of the study have important implications for sponsors and future research.

\section{Introduction}

Sponsorship is defined by Meenaghan (1983, p. 9) as: "provision of assistance either financial or in kind to an activity by a commercial organization for the purpose of achieving commercial objectives". There are only two parties involved in sponsorship, namely the sponsor- party which pays in any form in order to be associated with a specific property and the sponsee- property which offers value through association (Fullerton, 2007).

Sponsorship has received unprecedented investment in recent decades. The global sponsorship spending was calculated as \$25.9 billion in 2003 and in a decade this figure more than doubled and has reached to $\$ 53.3$ billion in 2013 despite the economic recession in 2008 and 2009 (IEG, 2013). In Europe,

${ }^{*}$ Research Assistant, Yildiz Technical University, Turkey.

${ }^{\dagger}$ Associate Professor, Marmara University, Turkey. 
sponsorship spending was estimated as $\$ 14.5$ billion in 2012 , with a $2.8 \%$ increase from the previous year (IEG, 2013). Similar to global trends, there is an increase in sponsorship spending in Turkey but the exact figures of sponsorship investment in Turkey is unknown (Bayindir, 2013). Continuous upward trend in sponsorship spending shows that companies consider it as a sound investment (Kim, Ko, \& James, 2011).

Approximately two thirds of all sponsorship spending is directed to sport properties (IEG, 2013). There are several reasons underlying for the dominance of sport in sponsorship market. Mullin, Hardy and Sutton (2007) argue that marketing transformed as a global activity and global companies need to communicate with their target markets in different languages and sport has ability to transcend borders. In a study which seeks to explain companies' intentions to engage in sport sponsorhip, sponsors of rugby clubs ranked their motives for engaging in sponsorship and top 5 responses were; increasing public awareness regionally, changing public perception of company, enhancing company image, increasing target market awareness and enhancing staff relations and motivation (Thwaites \& Carruthers, 1998). Another study showed similar findings and the most important objectives by corporate sponsors of a university athletic team were listed as increasing company/brand awareness, increasing sales, reinforcing/establishing image and increasing new customers (Weight, Taylor, \& Cuneen, 2010). Corporations ultimately want to impact their bottom line through engagement in sponsorship and as the investment in sponsorship escalates, it also draws attention from academia where several studies are made to demonstrate and evaluate returns of sponsorship (Walraven, Koning, \& Bottenburg, 2012). However, while the spending on sport sponsorship goes up, the need for justifying the returns of that investment increases as well (Pwc, 2011). Especially after 2003, corporations, which suffer from decreasing profits, started to question viability of sport sponsorship because of lack of convincing empirical evidence on its returns (Fullerton, 2007). Although the importance of determinants of effective sport sponsorship is evident, there is no generally accepted theory and there is a need for further exploration (Walraven, Koning, \& Bottenburg, 2012). This study is an attempt to contribute exploration and understanding of sport sponsorship effectiveness from a strategic perspective.

Several studies in the extant literature have used attitudes toward sponsor and purchase intentions of sport fans in order to assess the effectiveness of sport sponsorship (e.g. Kim, Ko, and James, 2011; Chih, et al., 2012; Thompson and Speed, 2000; Biscaia, Correia, Rosado, Ross and Maroco, 2013). Sponsors want to affect consumer behavior through forming a positive connection or a bond between the sponsor company and the sport fans that are already associated with a sport property such as a sport team, a sport organization or an athlete (Kim, Ko, \& James, 2011). A positive attitude is deemed as an important predictor of purchase intentions and in turn consumer purchase behavior (Ajzen, 2001). Furthermore, for the sponsor company, consumer purchase intention is one of the best tools to evaluate sponsorship effectiveness and studies should use intentions to purchase or trial rather than 
exposure, awareness and image improvement in order to assess the effectiveness of sponsorship (Crompton, 2004). In the current study, attitudes toward sponsor and future intentions of sport fans to purchase sponsor's products are used to evaluate effectiveness of sponsorship.

Basketball in Turkey is chosen as context of the present study since it is the second most popular sport type in Turkey (Yfu, 2013). According to laws in Turkey, only football, which is the dominating sport type, is considered as a professional sport and all other sports are regarded as amateur. In other words, basketball is the most popular amateur sport in Turkey. Sponsorship in basketball has been heavily used by corporations and almost all basketball teams in Turkey bear their main sponsor's company name (Tbl, 2014). Moreover, in 2004, a legislation change enabled companies to enjoy $100 \%$ tax relief on sponsorship expenditures on amateur sports and since then spending on sponsorship has increased considerably. Despite the recent growth, there is ample room for growth in sponsorship spending compared to the size of sport industry in Turkey (Ekmekci, 2013).

This study has contributions to sport sponsorship literature and expands understanding of sport sponsorship's effects on attitudes and purchase intentions of sport consumers. The current research adds literature by examining the antecedents of effective sport sponsorship in a non-western fans context, where there is a lot of room for sport sponsorship growth. Moreover, although the influence of sincerity on attitude towards sponsor has been widely studied in literature, the predictors of sincerity have rarely been sought. Hence, another significant contribution of the current study is investigating the effects of perceived fit and team attachment on perceived sincerity.

\section{Research Model and Conceptual Framework}

Conceptual model of the current study incorporates five factors to evaluate sport sponsorship effectiveness, namely these are team attachment, perceived sincerity, perceived fit, attitudes toward sponsor, and purchase intentions. Perceived fit and team attachment were taken as antecedents of perceived sincerity which is hypothesized to positively influence attitudes toward sponsor. Attitudes toward sponsor and perceived fit are the two constructs that were expected to have direct positive impact on intentions of sport consumers to purchase sponsor's products. Proposed conceptual model is given in Figure 1 and related hypotheses are developed below. 
Figure 1. Hypothesized Model

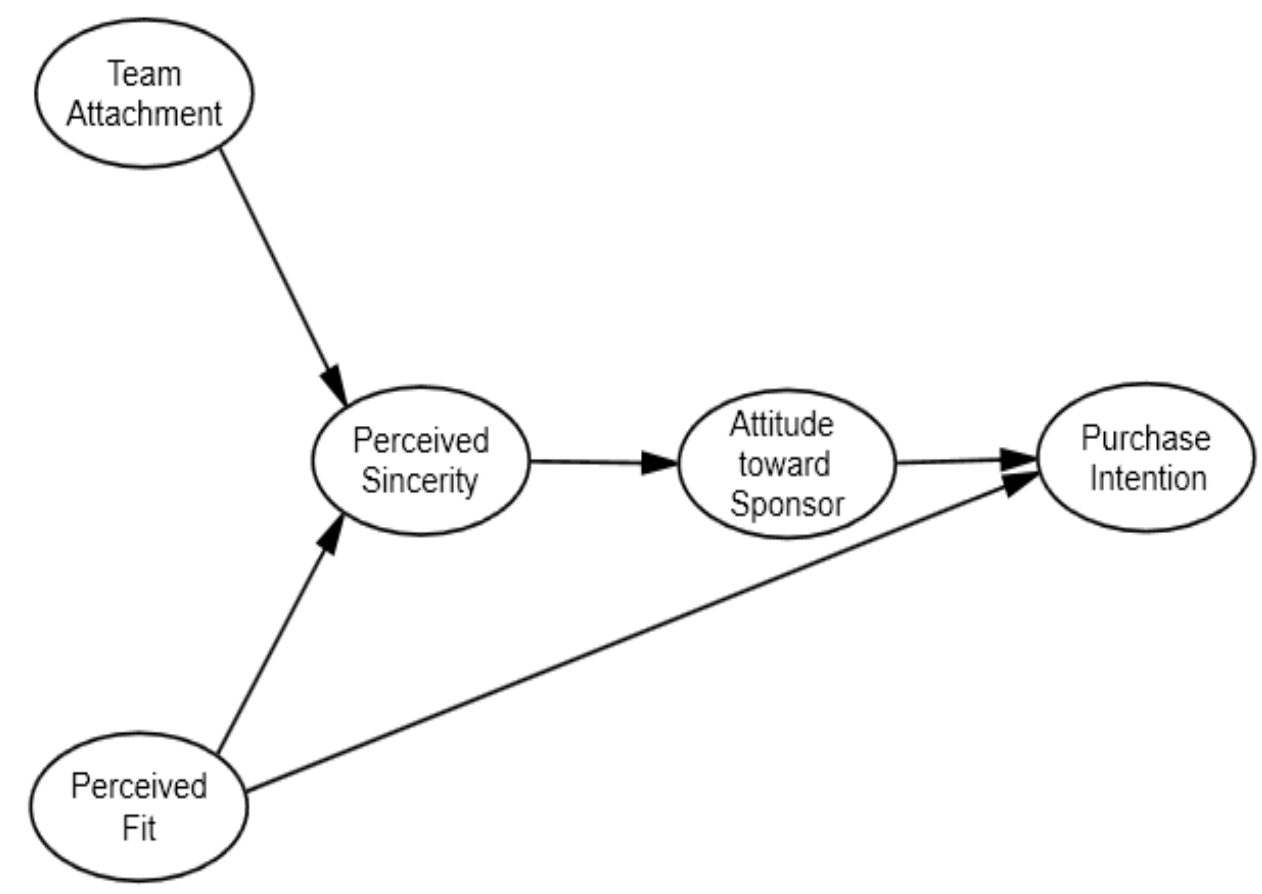

Attitude toward Sponsor and Purchase Intentions

Fishbein and Ajzen (1975, p. 6) defines attitude as:" A learned predisposition to respond in a consistency favorable manner with respect to a given object". Many studies have been made to examine the relationship between the attitude and behavior and attitudes are considered as important predictors of social behavior (Ajzen, 2001). A fan's overall impression of a sponsor is called as attitude toward sponsor (Gwinner \& Swanson, 2003) and a sport fan's willingness to buy and use sponsor's products is accepted as purchase intentions (Lee, Sandler, \& Shani, 1997).

In sponsorship literature, the connection between attitudes and purchase intentions has been investigated and well-established in several studies (e.g. Kim, Ko and James, 2011; Chih, et al., 2012; Biscaia, Correia, Rosado, Ross and Maroco, 2013; Madrigal, 2001). Based on the emprical evidence from previous studies, the current study hypothesizes:

H5. Attitudes toward the sponsor is positively associated with the intentions of sports consumers to purchase the sponsor's products

\section{Team Attachment}

A sport consumer's psychological connection to a sport team is called as team attachment (Alexandris \& Tsiotsou, 2012). It is suggested that a consumer's response to sponsorship is positively influenced by the strength of relationship between the consumer and the sponsored object (Meenaghan T. , 2001). In a study, this view was extended to examine consumers' perceptions of sponsor motives and it was empirically found that consumers who have higher level of relational bond with their favorite sport team are more inclined 
to believe that sponsor carries sincere motives for supporting their team (Kim, Ko, \& James, 2011). Thus, $H 1$ is formulated:

$H 1$. Team attachment is positively associated with perceived sincerity

\section{Perceived Fit}

It is generally accepted that if target audience see the sponsor and sponsored objects as congruent, that sponsorship is more likely to arouse positive responses (Walraven, Koning, \& Bottenburg, 2012). Thompson and Speed (2000) found that consumers who perceive fit between the sponsor and the sponsee are more inclined to form positive attitudes toward sponsor and use sponsor's products. There are several studies which showed similar findings reinforcing the positive relationship between the perceived fit and behavioral intentions (e.g. Becker-Olsen and Simmons, 2002; Cornwell, Weeks and Roy, 2005; Menon and Kahn, 2003; Olson, 2010). Based on the preceding, H4 is hypothesized:

H4. Perceived fit between the sponsor and the sport team is positively associated with the intentions of sports consumers to purchase the sponsor's products

Rifon, Choi, Trimble and Li (2004) found that fit is a positive predictor of sincreity and Olson (2010) reached similar results and found that fit has a positive influence on sincerity perceptions of sport fans.

Therefore, $H 2$ is formulated:

$H 2$. Perceived fit between the sponsor and the sport team is positively associated with perceived sincerity

\section{Perceived Sincerity}

Previous studies empirically showed that if motives of sponsor are perceived as philanthropic and sincere, they are more likely to receive positive responses to their sponsorship than the sponsors that are regarded as carrying solely commercial motives (Thompson and Speed, 2000: Armstrong, 1987). In another study, mediating role of sincerity, which is transmitting sport fans' psychological connection from a sport property to sponsor, between relationship quality and attitude toward sponsor has been established (Kim, Ko, \& James, 2011). Similarly, Olson (2010) found that sincerity enables fans to carry more positive and favorable attitudes toward the sponsor. Reflecting the mentioned empirical findings, $H 3$ is formulated:

H3. Perceived sincerity of the sponsor is positively associated with sport consumers' attitudes toward the sponsor

\section{Methodology}

In the current study a descriptive, single cross-sectional research design was implemented and self-administered structured survey method was used. Questionnaires were filled by spectators who were attending a professional Turkish Basketball League game in Istanbul. The questionnaires were 
distributed and collected before the start of a game in the arena by a team of 6 trained researchers. Out of 360 questionnaires distributed, 283 of them were deemed as usable.

Scales used in the current study were adapted from extant literature and wording of the previous scales are slightly changed to adapt the research context. Because respondents were Turkish fans and the original scales were in English, a back-translation technique (Brislin, 1990) was used to establish meaning consistency.

\section{Research Instruments}

Perceived fit and perceived sincerity, both have four items, were included in the study. Items in both constructs were adapted from the scales used by Thompson and Speed (2000). For team attachment construct, a four item scale used by Alexandris and Tsiotsou (2012) was adapted. For the three aforementioned factors, participants responded to the items using a five point Likert scale anchored by Strongly Disagree (1) and Strongly Agree (5).

In order to measure attitudes toward sponsor 5 point semantic differential scale items used by Lee and Cho (2009) were implemented-“'Overall, my attitude toward the sponsor brand is: negative/positive; unfavorable/favorable; bad/good; and dislikable/likable".

The last construct in the study is sport consumers' future intentions to buy sponsor's products and two items from Thompson and Speed (2000) were modified to measure purchase intention for sponsor's products. A five point Likert scale that is anchored by Strongly Disagree (1) and Strongly Agree (5) was used to measure purchase intentions of sport consumers.

\section{Data Analysis Results}

Demographic characteristics of the participants include gender, age, monthly income and education level as illustrated in the Table 1.

Majority of the respondents (78.8 per cent) were male and the average age was 30, within age range between 18 and 60. Approximately one fourth of respondents earn less than $1000 \mathrm{TL}(\sim 325 \mathrm{EUR})$ per month whereas 22 per cent of them earn more than 5000 TL ( 1628 EUR). Respondents represent a highly educated group in which 43 per cent of them hold a bachelor's degree and 15 per cent of them either hold or study towards a graduate degree. A big majority of the respondents replied "Yes" when they were asked if they follow their favorite basketball team's official Facebook and Twitter accounts. 
Table 1. Demographic Profile of Respondents

\begin{tabular}{|c|c|c|c|}
\hline & & $\mathbf{N}$ & Percent $(\%)$ \\
\hline \multirow{2}{*}{ Gender } & Male & 223 & 78.8 \\
\hline & Female & 60 & 21.2 \\
\hline \multirow{5}{*}{ Age } & 19 or less & 30 & 10.6 \\
\hline & $20-24$ & 58 & 20.4 \\
\hline & $25-29$ & 76 & 26.8 \\
\hline & $30-34$ & 51 & 18.1 \\
\hline & 35 or more & 68 & 24.1 \\
\hline \multirow{6}{*}{ Monthly Income } & Less than $1000 \mathrm{TL}$ & 70 & 24.7 \\
\hline & $1001 \mathrm{TL}-2000 \mathrm{TL}$ & 41 & 14.5 \\
\hline & $2001 \mathrm{TL}-3000 \mathrm{TL}$ & 51 & 18 \\
\hline & $3001 \mathrm{TL}-4000 \mathrm{TL}$ & 38 & 13.4 \\
\hline & $4001 \mathrm{TL}-5000 \mathrm{TL}$ & 19 & 6.7 \\
\hline & 5001 TL or more & 64 & 22.6 \\
\hline \multirow{7}{*}{ Education Level } & Primary School & 13 & 4.6 \\
\hline & High School & 30 & 10.6 \\
\hline & Associate Degree & 13 & 4.6 \\
\hline & Undergraduate student & 63 & 22.3 \\
\hline & Undergraduate & 122 & 43.1 \\
\hline & Graduate Student & 20 & 7.1 \\
\hline & Graduate & 22 & 7.8 \\
\hline \multirow{2}{*}{ Twitter \& Facebook } & Yes & 207 & 73.1 \\
\hline & No & 76 & 26.9 \\
\hline Total & Total Respondents & 283 & 100.0 \\
\hline
\end{tabular}

Turkey is ranked $7^{\text {th }}$ in the list which ranked countries with the highest number of Facebook users (Nierhoff, 2013) and Turkey has the highest internet users-Twitter users ratio all around the world; more than 11 million out of 36 million internet users in Turkey use Twitter (T24, 2013). Therefore, trace of extensive use of Facebook and Twitter in Turkey can also be seen in following favorite sport teams on two aforementioned social media channels.

\section{Data Accuracy Analysis}

A confirmatory factor analysis (CFA), construct reliability (CR) indexes, and average variance explained (AVE) are included in data accuracy analysis. The data was subjected to scale purification using CFA. Based on the scale parsimony and theoretical relevance of the items 5 items were eliminated and 18 items were left. Measurement model was evaluated through conducting CFA in AMOS 19.0 program. According to guidelines of global model fit assessment (Weston and Gore, 2006; $\mathrm{Hu}$ and Bentler, 1999), the global fit indices show good fit between hypothesized measurement model and observed data $\left(\chi^{2} / d f=202.15 / 109, \mathrm{RMSEA}=0.55, \mathrm{CFI}=0.97, \mathrm{TLI}=0.97, \mathrm{GFI}=0.92\right)$. 
Table 2. Illustrates Factor Loadings, Average Variance Extracted, and Construct Reliability of Factors

Team Attachment

Factors and Items

$\lambda$

AVE

CR

0.72

0.91

I feel like I am a member of the basketball

\section{team}

The team is important part of my life

0.87

0.87

0.81

0.84

I believe that I work for the good of the team

Perceived Fit

There is a logical connection between the team and the sponsor

The image of the team and the image of the sponsor are similar

The sponsor and the team fit together well

The sponsor and the team stand for similar things

Perceived Sincerity

This sponsor would probably support the team even if it had a much lower profile

The main reason the sponsor would be involved in the team is because the sponsor believes the team deserves support

The sport would benefit from this sponsorship at the grassroots level

The sponsor would be likely to have best interests of the sport at heart

Attitude towards sponsor

Overall, my attitude toward sponsor brand is (Unfavorable/Favorable)

Overall, my attitude toward sponsor brand is (Bad/Good)

Overall, my attitude toward sponsor brand is

(Dislikable/Likable)

Overall, my attitude toward sponsor brand is

(Negative/Positive)

Purchase intentions

This sponsorship would make me more likely to try the sponsor's products

This sponsorship would make me more likely to use the sponsor's products

*All loadings from CFA are significant at $p<0.01$ $\begin{array}{ll}0.68 & 0.89\end{array}$

0.76

0.86

0.88

0.79

0.59

0.85

0.65

0.92

0.89

0.94

0.95

0.94

0.88

0.94

Convergent validity was achieved since all factor loading in the same construct were significant and all loadings were higher than 0.60 . The construct reliability indexes are between 0.85 and 0.97 , all exceeding the threshold of 0.60 . Average variance extracted scores ranged between 0.68 and 0.89 , all of them higher than the limit 0.50 . The correlation of the specific construct with any other constructs in the model was less than the square root of AVE of each construct (Gefen \& Straub, 2005). For example, AVE score of team attachment 
factor was 0.72; and square root of AVE of team attachment factor was 0.85 was larger than the correlation of it with other factors (with sincerity: 0.45 , with attitude toward sponsor: 0.26, with sincerity: 0.45, with purchase intention: 0.32). All factors were checked in the same manner.

Structural model in Figure 1 was analyzed by using the structural equation modeling in AMOS 19.0 program. The results of the analysis showed an acceptable model fit $\left(\chi^{2} / d f=332.71 / 130, \mathrm{RMSEA}=0.74, \mathrm{CFI}=0.95, \mathrm{TLI}=0.95\right.$ and GFI= 0.89). In other words, proposed model converged well and can represent the empirical data structure collected in Istanbul, Turkey and the coefficients of research hypotheses are illustrated in Figure 2.

\section{Structural Model}

Based on the analysis, team attachment and perceived fit had significantly positive relationship with perceived sincerity (coefficients: 0.22 and 0.68 , respectively) thus supporting $H 1$ and $H 2$. Perceived fit also had a positive significant relationship with purchase intention (coefficient: 0.23), supporting H3. Perceived sincerity had a significant positive impact on attitudes toward sponsor (coefficient: 0.59 ), which in turn positively affects purchase intentions of sport consumers for sponsor's products (coefficient: 0.54). Therefore, H4 and $H 5$ were supported.

Figure 2. Final Model and Path Coefficients

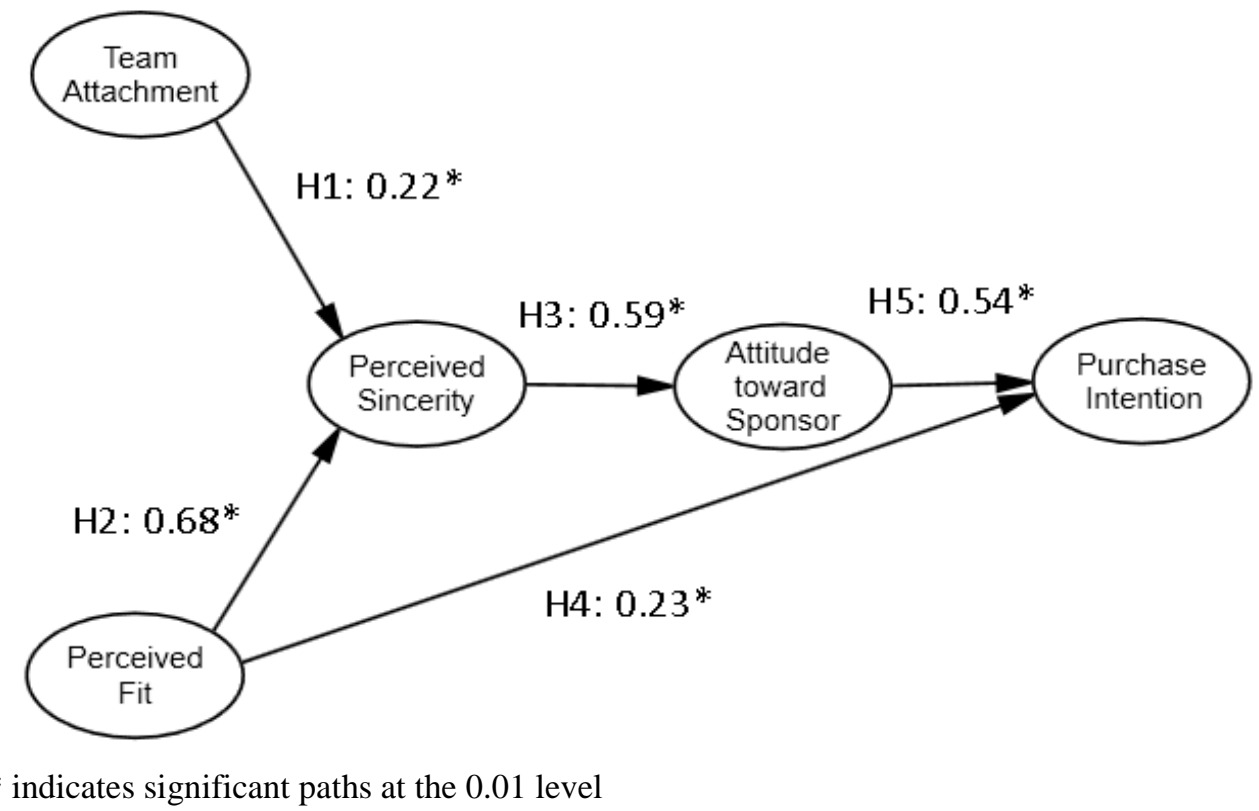

In the proposed model, the total, direct, and indirect effects on the endogenous variables were all significant and are illustrated in Table 3. All constructs used in the model have positive direct and/or indirect effects on purchase intentions. Attitude toward sponsor has the strongest positive effect 
on purchase intentions (0.54). Sincerity has a strong impact on attitude toward sponsor. Both fit $(0.68)$ and team attachment $(0.22)$ have positive effects on sincerity. Endogenous variables attitude toward sponsor, sincerity, fit, and team attachment explained $44 \%$ of the variance in purchase intentions.

Table 3. Direct, Indirect and Total Effects on the Endogenous Variable

Outcome Determinant Direct Indirect Total

Purchase Intention $\left(\mathrm{R}^{2}=0.44\right)$

$\begin{array}{cccc}\text { Attitude toward } & 0.54^{*} & - & 0.54 \\ \text { sponsor } & - & 0.32^{*} & 0.32 \\ \text { Sincerity } & - & 0.07^{*} & 0.07 \\ \text { Team } & & 0.22^{*} & 0.45 \\ \text { Attachment } & 0.23^{*} & & \end{array}$

Attitude toward sponsor

$\left(\mathrm{R}^{2}=0.35\right)$

Sincerity $\left(R^{2}=0.51\right)$

$\begin{array}{cccc}\text { Sincerity } & 0.59^{*} & - & 0.59 \\ \text { Team } & - & 0.13^{*} & 0.13 \\ \text { Attachment } & - & 0.40^{*} & 0.40 \\ \text { Fit } & - & \end{array}$

$\begin{array}{clll}\text { Team } & 0.22^{*} & - & 0.22 \\ \begin{array}{c}\text { Attachment } \\ \text { Fit }\end{array} & 0.68^{*} & - & 0.68\end{array}$

*indicates significant effect at 0.01 level

\section{Discussion}

As previously noted, this study sought predictors of sincerity perception of sport consumers and results showed that, in support of $H 1$ and $H 2$, sport fans, that have high level of team attachment and perceive that there is a fit between sponsor and sponsee, are more likely to believe that motives of the sponsor are sincere. Therefore, findings of the current study corroborate the previous studies focusing on the relationship between fit and sincerity (Rifon, Choi, Trimble, and Li, 2004; Olson, 2010) and studies focusing on the impact of team attachment on perceived sincerity (Kim, Ko, and James, 2011; Meenaghan T. , 2001). This is a very crucial contribution of the study since the literature has heavily examined the effects of perceived sincerity on attitude and purchase intentions but very rarely sought its predictors.

The current study empirically proved the postivite relationship between perceived sincerity and attitudes toward the sponsor, providing support for $\mathrm{H3}$ and substantiating findings of previous studies (Thompson and Speed, 2000; Gwinner and Bennett, 2008). It was found that perceived sincerity influences purchase intentions through attitude toward sponsor.

Perceived fit between the sponsor and the sponsored object has been proven to influence purchase intentions of sport consumers for sponsor's 
products (Koo, Quarterman, and Flynn, 2006; Close and Lacey, 2013) and current study, in support of $H 4$, reached similar findings reinforcing the connection between fit and purchase intentions.

Finally, providing support for $H 5$, current study's findings illustrated the positive impact of attitudes toward sponsor on purchase intentions in line with previous studies (Chih, et al., 2012; Gwinner and Bennett, 2008).

\section{Managerial Implications}

Because sponsorship is a commonly used marketing tool, the findings of the current study have important implications for marketers and managers.

Findings support for the suggestion of Kim, Ko, and James (2011) that if sport consumers perceive sponsor's motives as sincere, they are more likely to form positive attitudes toward the sponsor firm which positively affects their purchase intentions for sponsor's products. For managers, this result suggests that sponsoring firms should try to demonstrate and accentuate their altruistic aspects of their goals when sponsoring a sport team. Therefore, determinants of sincerity perception gains importance and the model argues that sport consumers, who are highly attached to their favorite teams and belives that there is a fit between the team and the sponsor are more likely to perceive motives of the sponsor sincere. Thus, sponsor firms need to focus on articulating a good fit between the sponsor and the sport team and reach to fans who have high team attachment. Furthermore, companies might be better off if they seek out a sport team with dedicated fans when engaging in a sponsorship.

Results of the study illustrated that attitudes toward sponsor and perceived fit positively influence purchase intentions of sport consumers. As noted before, the relationship between attitude toward sponsor and purchase intentions are well established and current study corroborates the findings of Gwinner and Bennett (2008). It is very crucial for a sponsor firm that a good fit between the sponsor and the sponsored team induces sport consumers to purchase sponsor's products so firms should endeavor to create a perception of fit.

Because this study is one the very few studies about the sport sponsorship in Turkey, it has crucial implications for companies that plan to engage in sponosorship. The study proves that factors that lead to a positive sponsorship response are viable when the sponsored object is a Turkish basketball team and the subjects are its fans. Therefore, corporations should take these factors and elements into consideration when engaging in sponsorship.

Another crucial point is that sport sponsorship, as mentioned previously, has a great potential for further development in Turkey, especially due to growing sport industry and the young population of the country with a keen interest in sports. This study underscores that this potential is worth investing because corporations can get several benefits if their sponsorship program is managed properly. 


\section{Limitations and Future Research}

Cross-sectional research was implemented in the current study. Although the directions of the effects were justified and all hypotheses were statistically supported, a longitudinal approach with experimental design may provide more cogent findings. Another point is that in the study questionnaires were selfadministered. Although it is a common method in the extant literature, selfreported measures might cause biases such as extreme and central tendency. Lastly, the study is confined to a particular group of people who are fan of a specific basketball team. Using one sport type, sport consumers of one team and one sponsor firm are the main limitations of the study and generalization should be made with prudence. Therefore, future studies should be made in different contexts in order to find out if the model works in the same way with different sport teams, sponsors and fans.

Investigating the predictors of perceived sincerity is a good point for future research. Although fit and team attachment were shown to be two determinants of sincerity perception, there might be other dimensions which have an influence on sincerity. Team attachment predicted a low proportion of variance in sincerity so this relationship demands further investigation.

\section{Conclusion}

The current study empirically examines the relationship among five constructs (i.e. purchase intention, attitude toward sponsor, perceived sincerity, perceived fit and team attachment) in Turkish basketball context where the respondents were spectators of a professional basketball game. A model was developed and empirically tested and the results of the study suggest that sport consumers who have high level of team attachment and perceive sponsor and sponsee as a fitting combination are more likely to believe that motives of the sponsor are sincere, and thereby they will develop positive attitude and in turn greater purchase intention. The contributions of the study are two-fold. Firstly, the current study proposed a model and a theoretical explanation for examining the determinants of effective outcomes of sport sponsorship. Secondly, the study added to scarce sport sponsorship literature regarding predictors of perceived sincerity. Despite the contributions of the study, further evaluation, extension and development is needed.

\section{References}

Ajzen, I. (2001). Nature and operation of attitudes. Annual Review of Psychology Vol. 52 No. 1, 27-58.

Alexandris, K., \& Tsiotsou, R. H. (2012). Testing a hierarchy of effects model of sponsorship effectiveness. Journal of Sport Management Vol. 26, 363-378.

Armstrong, C. (1987). Sport Sponsorship: A Case-Study Approach to Measuring Its Effectiveness. European Research Vol. 16 No. 2, 97-103. 
Bayindir, H. (2013, june 29). www.sabah.com.tr/Ekonomi/2013/06/29/sponsorlarinfestival-yaris. Retrieved 11 27, 2013, from www.sabah.com.tr: http://www.sa bah.com.tr/Ekonomi/2013/06/29/sponsorlarin-festival-yarisi

Becker-Olsen, K., \& Simmons, C. J. (2002). When do social sponsorships enhance or dilute equity? Fit, message source, and the persistence of effects. Advances in Consumer Research, Vol. 29 No. 1, 287-289.

Biscaia, R., Correia, A., Rosado, F., Ross, S. D., \& Maroco, J. (2013). Sport Sponsorship: The Relationship Between Team Loyaity, Sponsorship Awareness, Attitude Toward the Sponsor, and Purchase Intentions. Journal of Sport Management Vol. 27 No. 4, 288-302.

Brislin, R. W. (1990). Applied Cross-Cultural Psychology. Newbury Park, CA: Sage.

Chih, M., Wang, H., Jain, M., Ming, J., Cheng, S., Kyaw, G., et al. (2012). The purchasing impact of fan identification and sports sponsorship. Marketing Intelligence \& Planning Vol. 30 No. 5, 553-566.

Close, A. G., \& Lacey, R. (2013). Fit Matters? Asymmetrical Impact for Effectiveness on Sponsors and Event Marketers. Sport Marketing Quarterly Vol. 22, 71-82.

Cornwell, T. B., Weeks, C. S., \& Roy, D. P. (2005). Sponsorship-linked marketing: opening the black box. Journal of Advertising Vol. 34 No. 2, 21-42.

Crompton, J. L. (2004). Conceptualization and alternate operationalization of the measurement of sponsorship effectiveness in sport. Leisure Studies Vol. 23 No. 3, 267-281.

Ekmekci, R. (2013). New Era Sport Sponsorship in Turkey. Journal of Business and Management Sciences Vol. 1 No. 1, 10-13.

Euroleague. (2013, October 22). Retrieved March 8, 2014, from www.euroleague.net: http://www.euroleague.net/euroleague-basketball/news/i/120794/6330/turkishairlines-euroleague-basketball-cement-partnership-through-2020

Fishbein, M., \& Ajzen, I. (1975). Belief,Attitude, Intetion, and Behavior:An Introduction to Theory and Research. Reading,MA: Addison-Wesley.

Fullerton, S. (2007). Sport Marketing. New York: McGraw Hill.

Funk, D., Haugtvedt, C., \& Howard, D. (2000). Contemporary attitude theory in sport: Theoretical considerations and implications. Sport Management Review Vol. 3, No. 2, 125-144.

Gefen, D., \& Straub, D. (2005). A practical guide to factorial validity using PLSGraph: tutorial and annotated example. Communications of the Association for Information Systems Vol. 16, 91-109.

Gwinner, K., \& Bennett, G. (2008). The Impact of Brand Cohesiveness and Sport Identification on Brand Fit in a Sponsorship Context. Journal of Sport Management Vol. 22, 410-426.

Gwinner, K., \& Swanson, S. R. (2003). A model of fan identification: Antecedents and sponsorship outcomes. The Journal of Services Marketing Vol. 17, No. 3, 275-294.

Holt, R. (2013, 04 21). www.telegraph.co.uk/technology/twitter/9945505/Twitter-innumbers.html. Retrieved 11 28, 2013, from www.telegraph.co.uk: http://www.te legraph.co.uk/technology/twitter/9945505/Twitter-in-numbers.html

Hu, L., \& Bentler, P. M. (1999). Cutoff criteria for fit indexes in covariance structure analysis: conventional criteria versus new alternatives. Structural Equation Modeling Vol. 6 No. 1, 1-55.

IEG. (2013). IEG Special Report. Chicago: IEG.

IEG. (2013). IEG Sponsorship Report. Chicago: IEG. 
Kerstetter, D. L., \& Kovich, G. M. (1997). The involvement profiles of Division I women's basketball spectators. Journal of Sport Management Vol. 11, No. 3, 234-249.

Kim, Y. K., Ko, Y. J., \& James, J. (2011). The impact of relationship quality on attitude toward a sponsor. Journal of Business \& Industrial Marketing Vol. 26 No. 8, 566-576.

Ko, Y. J., Kim, K. K., Claussen, C. L., \& Kim, T. H. (2008, January). The effects of sport involvement, sponsor awareness and corporate image on intention to purchase sponsors' products. International Journal of Sports Marketing \& Sponsorship, 79-94.

Koo, G.-Y., Quarterman, J., \& Flynn, L. (2006). Effect of Perceived Sport Event and Sponsor Image Fit on Consumers' Cognition, Affect, and Behavioral Intentions. Sport Marheting Quarterly Vol. 15, 80-90.

Lee, H.-S., \& Cho, C.-H. (2009). The Matching Effect of Brand and Sporting Event Personality:Sponsorship Implications. Journal of Sport Management Vol. 23, 4164.

Lee, M.-S., Sandler, D. M., \& Shani, D. (1997). Attitudinal constructs towards sponsorship scale development using three global sporting events. International Marketing Review Vol. 14, No. 3, 159-169.

Madrigal, R. (2001). Social identity effects in a belief-attitude-intentions hierarchy: implications for corporate sponsorship. Psychology and Marketing Vol. 18, No. 2, 145-165.

Meenaghan, J. A. (1983). Commercial sponsorship. European Journal of Marketing Vol. 7 No. 7, 5-73.

Meenaghan, T. (2001). Understanding sponsorship effects. Psychology and Marketing Vol. 18 No. 2, 95-122.

Menon, S., \& Kahn, B. E. (2003). Corporate sponsorship of philanthropic activities: when do they impact perception of sponsor brand? Journal of Consumer Psychology Vol. 13 No.3, 316-27.

Mullin, B. J., Hardy, S., \& Sutton, W. A. (2007). Sport Marketing . Human Kinetics.

Nierhoff, M. H. (2013). www.quintly.com/blog/2013/02/facebook-country-statsfebruary-2013-top-10-countries-lose-users/. Retrieved 11 28, 2013, from www.quintly.com: http://www.quintly.com/blog/2013/02/facebook-country-statsfebruary-2013-top-10-countries-lose-users/

Olson, E. L. (2010). Does sponsorship work in the same way in different sponsorship contexts? European Journal of Marketing Vol. 44 No. 1/2, 180-199.

Pwc. (2011). Changing the Game. London: PWC.

Rifon, N. J., Choi, S. M., Trimble, C. S., \& Li, H. (2004). Congruence effects in sponsorship. Journal of Advertising, Vol. 33, Spring, 29-42.

Simmons, C. J., \& Becker-Olsen, K. L. (2006, October). Achieving Marketing Objectives Through Social Sponsorships. American Marketing Association Vol. 70 No. 4, 154-169.

Stotlar, D. K. (2004). Sponsorship Evaluation: Moving from Theory to Practice. Sport Marketing Quarterly Vol.13 No.1, 61-64.

T24. (2013, 10 06). t24.com.tr/haber/turkiye-twitterda-dunya-sampiyonuoldu/241294. Retrieved 11 28, 2013, from t24.com.tr: http://t24.com.tr/haber/ turkiye-twitterda-dunya-sampiyonu-oldu/241294

Tbl. (2014). Retrieved March 08, 2014, from www.tbl.org.tr: http://www.tbl.org.tr/ beko/index.asp?sezon=2013-2014

Thompson, P., \& Speed, R. (2000). Determinants of Sports Sponsorship Response. Journal of the Academy of Marketing Science Vol.28 No.2, 226-238. 
Thwaites, D., \& Carruthers, A. (1998). Practical Applications of Sponsorship Theory: Empirical Evidence From English Club Rugby. Journal of Sport Management Vol.12, 203-219.

Walraven, M., Koning, R. H., \& Bottenburg, M. V. (2012). The effects of sport sponsorship: A review and research agenda. The Marketing Review Vol.12 No.1, 17-38.

Wann, D. L., \& Branscombe, N. R. (1993). Sports fans: Measuring degree of identiication with their team. International Journal of Sport Psychology Vol. 24, $1-17$.

Weight, E., Taylor, K., \& Cuneen, J. (2010). Corporate Motives for Sport Sponsorship at Mid-Major Collegiate Athletic Departments. Journal of Issues in Intercollegiate Athletics Vol.3, 119-130.

Weston, R., \& Gore, P. A. (2006). A brief guide to structural equation modeling. The Counseling Psychologist Vol. 34, No. 5, 719-51.

Yfu. (2013). Retrieved March 11, 2014, from www.yfu-turkey.org: http://www.yfuturkey.org/welcome-to-turkey/leisure-time 
